\title{
"Evaluation of the economic effectiveness of investments in commercial real estate using the switch option"
}

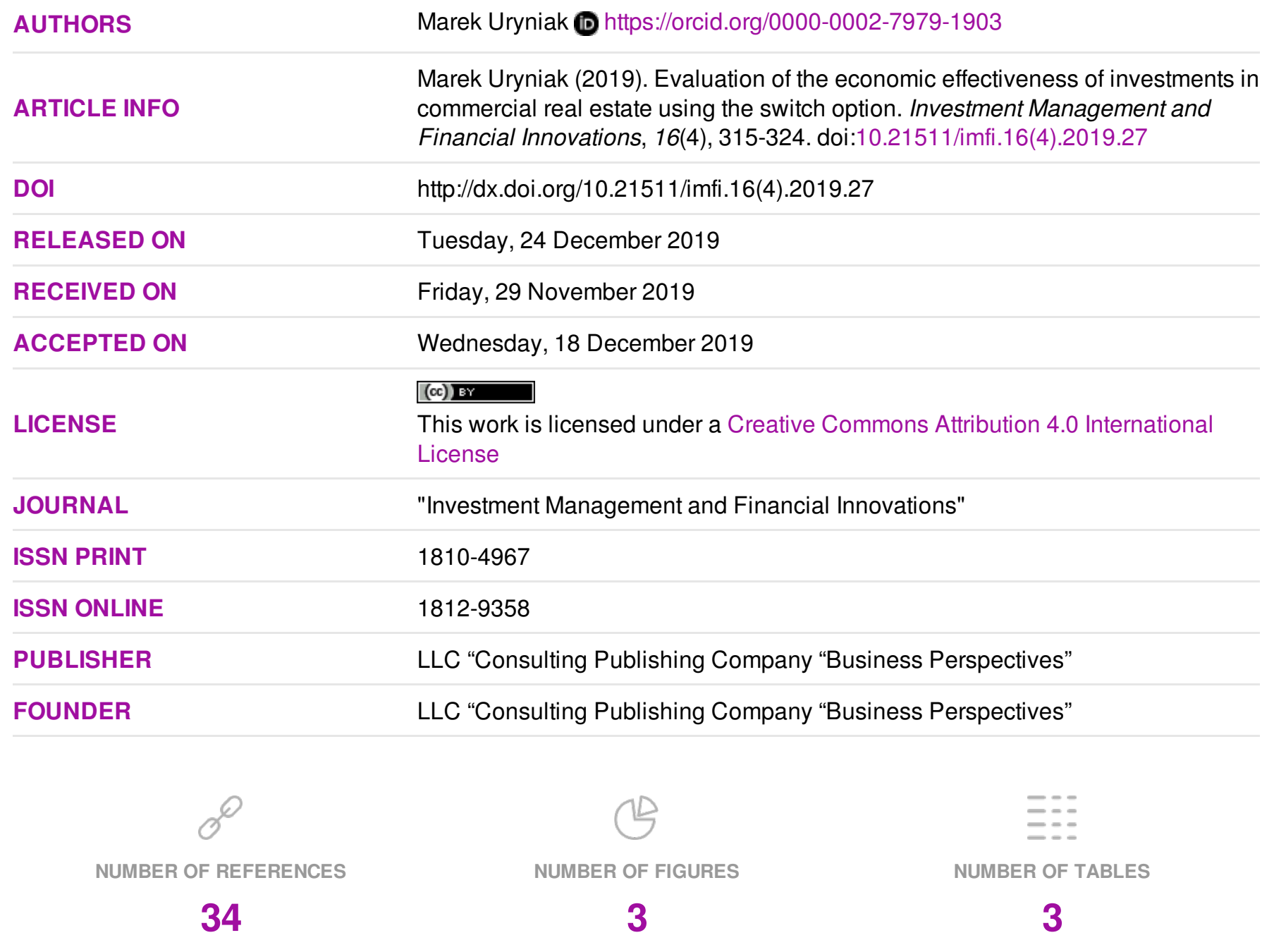

(c) The author(s) 2023. This publication is an open access article. 


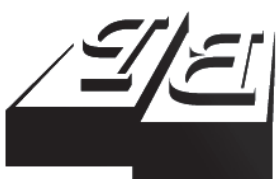

BUSINESS PERSPECTIVES

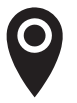

LLC "CPC "Business Perspectives" Hryhorii Skovoroda lane, 10, Sumy, 40022, Ukraine

www.businessperspectives.org

Received on: $2^{\text {th }}$ of November, 2019 Accepted on: $18^{\text {th }}$ of December, 2019

(C) Marek Uryniak, 2019

Marek Uryniak, Ph.D., Rzeszow University of Technology, Poland.

\section{(c) (i)}

This is an Open Access article, distributed under the terms of the Creative Commons Attribution 4.0 International license, which permits unrestricted re-use, distribution, and reproduction in any medium, provided the original work is properly cited.

\section{EVALUATION OF THE ECONOMIC EFFECTIVENESS OF INVESTMENTS IN COMMERCIAL REAL ESTATE USING THE SWITCH OPTION}

\begin{abstract}
Deciding whether an investment should be made or not requires an evaluation of the investment's effectiveness. The choice of evaluation methods is related to the basic objective conditioning the implementation of the investment project. It often happens that the conditions in which a specific investment has been formulated change and so does the basis for its implementation, and it is necessary to adapt it to the new conditions. These new conditions could be recognized during the exploitation of the project so it is hard to take them into consideration at the stage of planning. The paper aims to evaluate the investments in commercial real estate with the option of alternative way of usage. This evaluation was carried out using the classical (discounted) methods of economic efficiency of investments and real options. Two groups of pricing real options models were used in the study: binomial models and continuous-time models. Results based on varied valuation methods lead to different conclusions. Unlike the discount methods, the real option approach allows valuing the project flexibility (which cannot be valued by classical methods). This value of flexibility in certain conditions indicates what should be the path of development of the project related with the transformation of commercial real estate for other purposes.
\end{abstract}

\section{Keywords}

commercial real estate, investments, investments evaluation, economic effectiveness, switch option, real options valuation

\section{JEL Classification G30, G31}

\section{INTRODUCTION}

The problems discussed in the paper focus on the issues related to with the evaluation of the economic effectiveness of investments in commercial real estate. Making the decisions connected with implementation of a specific investment project, the effects of which will appear in the future, is associated with risk and uncertainty. Therefore, a particular investment decision is made based on certain criteria (usually financial) adopted at the time of planning the investment. In the current practice of evaluation, the economic efficiency of investments, many methods are used, taking into account the risk and uncertainty in this evaluation, however, in relation to the commonly used classical methods, various types of imperfections are indicated (Mun, 2002). Their identification is the basis for the search for new methods of evaluating the effectiveness of investments reducing these imperfections, while allowing for the inclusion of risk and uncertainty in this calculation.

The results of these searches are real options, which were developed based on financial derivative instruments. In case of fixed investments, the real option method allows defining and evaluating the selected investment projects. 


\section{LITERATURE REVIEW}

People use real estate (consciously or unconsciously) in many (if not all) aspects of socio-economic life (Tanas, M. Trojanek, \& R. Trojanek, 2019; R. Trojanek, Tanas, \& M. Trojanek, 2019). In light of the binding in Poland, the real estate (Civil Code, 1964) can be divided into land properties, buildings, and apartments. Taking the functions fulfilled by real estate as a criterion, they can be divided into residential, agricultural, and forest, industrial and recreational properties and leisure, special purpose, commercial. When this criterion is the possibility of earning the income, the real estate can be divided into commercial, speculative, and capital (Kwiatkowska, 2003). As in case of the basic division, real estate is a collection of various types of buildings, including (Foryś, 2006):

- office real estate;

- commercial real estate;

- $\quad$ service real estate.

The basic feature of commercial real estate is, as it wasalready mentioned, an ability to generate the income (Gawron, 2006) and they can be treated as a long-term capital investment (Uhruska, 2007).

The various ways of usage of real estate in business operations allow us to describe them using several functions (Bryx, 2006; Kucharska-Stasiak, 2006). These functions depend on the value in use related with the property, which implies the manner of their economic usage (Matkowski, 2004).

The abovementioned comments and the observation of business activities allowed stating that real estate is one of the main directions of investment.

In general, investments are any capital commitment that is used to increase the capital or expenditures made to obtain certain benefits in the future. This approach to the investment corresponds with the feature of commercial real estate related to the possibility of generating the income.

Investing in real estate not only is a real assets investment but also a financial investment. On the one hand, investors will incur specific investment outlays for the creation, reconstruction, modernization, etc. of certain real estate assets. Otherwise, capital expenditures will be related to investing the financial resources in planned or already existing real estate, in order to limit the risk, multiply the capital, etc., based on co-ownership.

Making the investment decisions on the real estate market is a complex process. This is mainly due to the characteristics owned by the real estate, and above all, the high capital intensity of investment in real estate, high transaction costs, and low liquidity of real estate (Kucharska-Stasiak, 2001). This high capital intensity in connection with the risk of investing means that the payback period of the capital involved is relatively long and the investor cannot expect the quick return on this kind of investment (Kucharska-Stasiak, 2005). Generally, deciding on the investment is the most important stage in the investment process. This is due to investment features, which can include (Lewczyński, 1994):

- the involvement of usually considerable amount of money;

- the occurrence of an uncertainty and risk on a larger scale than in operative decisions, the effects of which are short-lived because investment processes often run over a long time;

- once made decisions are difficult to reverse if they prove to be useless;

sometimes the success or failure of a business depends on one investment decision;

- implementation of investments in a long-term manner shapes the demand for current assets necessary for the exploitation of newly created fixed assets.

From the point of view of evaluation of investment economic effectiveness, risk and uncertainty are of special significance among these features because they can significantly influence the real value of the investment project. In case of commercial real estate, both macroeconomic (Szmyd-Śmietana, 1999) and microeconomic (Kucharska-Stasiak, 1999) factors influence the size of the risk. However, it is not possible to indicate one universal list of specific risks to all commercial real estate, as there 
are no two identical properties. However, whether a particular commercial real estate should be considered as a subject of investment, determines the result of the economic investment efficiency evaluation, which is the answer on the question whether the investment is profitable or not (from the point of view of financial evaluation).

\section{METHODS}

Making an investment decision requires from the decision makers the comprehensive knowledge related to a specific investment project. The main problem faced by the decision makers is choosing the right criteria for making investment decision. Experience to date in this area is based on the use of a financial criteria to make the investment decision, i.e., a calculation of the economic effectiveness of the investment. In general, the calculation of the economic effectiveness of investments is the sum of calculations aimed at comparing the results obtained during the period of operation from the completed investment with the expenditure necessary to achieve them. In other terms, the calculation of the effectiveness of investment projects includes the preparation of data and evaluation of the effectiveness of investment projects, taking into account the risk related with their implementation and making an investment decision. According to this, an evaluation can be made using a number of methods for evaluating the economic effectiveness of the investment.

Interesting way of describing the general classification of methods for evaluating the economic effectiveness of investments was presented by Pera (2010).

According to Pera (2010), the existing division into static and dynamic methods is too general. This applies in particular dynamic methods, and especially the meaning of "dynamic." He states that "the methods of evaluating the investment projects can be considered dynamic only when the evaluation consists in the valuable expression of many possible scenarios for the implementation of the investment and allows for the valuation of the project's flexibility," but not in relation to methods based on using the time factor in the investment efficiency evaluation by discounting of cash flows (Pera, 2010, p. 148).
Regarding the investments in commercial real estate, it is possible to use the methods for evaluation the economic effectiveness of investments, as they generate the income. In this study, NPV and MIRR (Pluta, Jajuga, 1995; Nowak, Pielichaty \& Poszwa, 1999; Kurek, 2000) methods were selected to determine the economic effectiveness of the investment. The use of these methods requires (as discussed earlier) the inclusion of the risks and uncertainties accompanying the investment project. Not including them in the evaluation of the effectiveness of investment projects may be the cause of an incorrect evaluation leading to the wrong decision regarding the implementation of the investment project. In order to avoid this in practice, the investment effectiveness evaluation uses many methods that take into account the risk phenomena and the uncertainties.

The effect of searching for "better" methods for assessing the economic effectiveness of investments are real options (Myers, 1977), allowing for the valuation of the so-called project flexibility. It is about the possibility of dynamic management of the investment project during its operation and reacting to unfavorable phenomena that affect its effectiveness.

In general, real options can be defined as "the right (and not the obligation) to take certain actions in the future. The option holder uses this right (i.e., the option is exercised) when it is beneficial for him."

A real option has special value when the investments projects are accompanied by high uncertainty or when the market is volatile - this is because uncertainty creates value. In this approach, the correct use of the option can only increase the value of the investment (Jajuga, 2002). This is related to the aforementioned uncertainty accompanying the investment projects, which significantly affects the value of the project (Amram \& Kulatilaka, 1999).

In the traditional approach to the valuation of assets, a higher level of uncertainty is accompanied by a lower value of assets. The approach based on the use of real options shows that an increase in the uncertainty leads to an increase in the value of assets in case of recognizing and using the options for flexible reaction to the development of accidents. 
In contrast to the classic methods of assessing the investment projects that allow deciding on its implementation or rejection, real options are characterized by the following (Mizerka, 2005):

- the decision maker realizing that he is making the decisions under conditions of uncertainty, tries to take into account the possibilities that open as a result of his decision, as well as the interrelationship between these possibilities;

- the use of certain opportunities in the future (using the option) depends on the development of the situation; therefore, the decisionmaker's ability to react to changes in the environment is assumed.

Using the above-discussed essence of real options, it can easily be concluded that their use in business operations is of key importance in the context of investments made by business entities. The commonly used mechanism of project evaluation using the discounted cash flows is not sufficient to make a decision beneficial from the point of view of maximizing the company's profit by pursuing profitable investments. In fact, there are many problem areas that an analyst using the discounted cash flow models should be aware of. The basic one concerns the economic reality, with a high level of risk and uncertainty at the moment of making the decisions, and the possibility of flexible management and change of decisions in a situation when this uncertainty will become known over time (Mun, 2002). The investment plan based on future inflows and outflows is the result of optimization, however, revenues from sales and profits are subject to uncertainty, and the logic of the discounted cash flow method assumes an optimal plan of investment expenditures in connection with the expected effects. The discounted cash flow method does not include possible decisions, and its basic assumption is "we are moving forward" (Amram, 2002).

It is extremely difficult to classify the real options clearly and unambiguously. In the short history of their practical use, many types of options have emerged, and their diversity is related to the possibilities of investment activities at subsequent stages of the investment process. Depending on the achieved result of the completed stage of the invest- ment project and the market situation, the investor may implement the next stage of the investment project, postpone its implementation, refrain from implementing the project or its parts, etc.

The basic division of options is related to the specificity of the investment project. One can distinguish between internal (inherent options) and created options. The internal option is associated with a specific investment project and it depends only on the investment project evaluator if this option will be noticed. The opposite option is the created option, i.e., one that can occur after incurring additional investment outlays (Ruijter \& Janssen, 2005).

A large number of types (Copeland \& Keenan, 1998; Petersen \& Bason, 2001) of real options is related to the nature of the investment activity being undertaken or already carried out and the kinds of investments dependent on the external and internal conditions changes. Awareness of the situation, where the investment project is located and limitation the degree of uncertainty coming from identification the sources of risk and uncertainty, which at the moment of deciding on the implementation of the investment project was not known, they allow the decisionmakers to adopt an appropriate strategy regarding the future of the investment project. However, it should be remembered that each such decision is related to the valuation of the investment project's value based on specific methods.

The aforementioned valuation of real options depends on many factors. The basic one is related to the type of option (one or several) taken into account in connection with the implementation of a specific investment project. The value of real options can be estimated using different approaches, characterized by different levels of difficulty and the quality of the results obtained (Borison, 2003). Within them, two groups of pricing real options models are used: binomial models and continuous-time models. The binomial tree method consists in dividing the time until the option expires into discrete intervals and assuming that in each of these ranges, the value of the underlying asset (current value of cash flows from the project) changes abruptly in the binomial process (Cox, Ross, \& Rubinstein, 1979). Application of a specific method belonging either to the binomi- 
al or continuous group of methods requires the calculations of basic components and parameters (Wiśniewski, 2008; Mun, 2002).

\section{RESULTS}

This section presents the results of the analysis of the economic effectiveness of investments in commercial real estate. In reference to the remarks concerning the distinction between methods of the calculation of economic efficiency of investment, the valuation was carried out in two ways. The selected investment in commercial real estate was evaluated using the NPV and MIRR discount methods and the real options methods (in this case, the switch or convert options).

The evaluated investment project is a shopping center (SC), built based on post-production real estate. Modernization of the building was carried out in a way that allows using the space previously used as commercial space for office space (OS). Among the factors affecting the conversion of the existing commercial space to office space there can be mentioned a significant increase in the supply of commercial space, higher architectural standards of real estate for commercial activities, the prospect of building new commercial real estate, increased demand for office space.

Table 1 presents the data necessary to calculate the shopping center NPV and MIRR.

The net present value of cash flows calculated based on the data contained in Table $1(\mathrm{NPV}=-253.59$ thousand PLN) indicates the lack of profitability of the project in this form (in this case, the MIRR was not calculated). A negative evaluation of economic efficiency means difficulties for the owners in recovering the incurred financial outlays related to the analyzed property in a short time. In the longterm, the payback of investment outlays is possible, which results from the fact of generating positive cash flows from the conducted activity.

Similarly, an investment related project was evaluated with the transformation of commercial space to office space. For the moment of the change of the purpose of the real estate, the year 7 has been adopted. This year, investment outlays are appearing related to the transformation of commercial space into office space. Starting from this year, higher revenues were also assumed (higher rent price of $1 \mathrm{sq} \mathrm{m}$ of office space). Table 2 summarizes the necessary categories to calculate the value of net cash flows, NPV, and MIRR from year 7 because in the years from 0 to 6 , the values are analogous to those in Table 1.

Calculated values of NPV $=125.62$ thous. PLN and MIRR $=8.2 \%$ give the basis for a decision to transform commercial space into office space. To this end, one needs to incur the capital expenditures PLN 500.00 thousand. The current value of inflows exceeds the current value of expenses by the amount of PLN 125.62 thousand and the rate of return by $1 \%$ higher than the assumed cost of capital in the 10-year calculation period, however, do not make this project financially profitable, though, the light of the assumed criteria, meets the requirement of efficiency.

Table 1. Data for calculating cash flow of shopping center

\begin{tabular}{|c|c|c|c|c|c|c|c|}
\hline Years & Expenditures & Inflows & Expenses & Tax & Cash flow & $\begin{array}{l}\text { Discount rate for } \\
r=8 \%\end{array}$ & Current value \\
\hline 0 & $8,500,00$ & - & - & - & $-8,500,00$ & 1.000 & $-8,500,00$ \\
\hline 1 & - & $1,088,95$ & 546,16 & - & 542,79 & 0.926 & 502,58 \\
\hline 2 & - & $2,471,01$ & 830,59 & - & $1,640,42$ & 0.857 & $1,406,39$ \\
\hline 3 & - & $2,165,79$ & 765,50 & - & $1,400,29$ & 0.794 & $1,111,59$ \\
\hline 4 & - & $2,144,21$ & 845,84 & 246,69 & $1,051,68$ & 0.735 & 773,01 \\
\hline 5 & - & $1,866,76$ & 710,11 & 219,76 & 936,89 & 0.681 & 637,63 \\
\hline 6 & - & $2,053,44$ & 745,62 & 234,30 & $1,059,33$ & 0.630 & 667,56 \\
\hline 7 & - & $2,374,52$ & 753,07 & 308,07 & $1,313,37$ & 0.583 & 766,34 \\
\hline 8 & - & $2,611,97$ & 768,14 & 350,33 & $1,493,51$ & 0.540 & 806,90 \\
\hline 9 & - & $2,742,57$ & 783,50 & 372,22 & $1,586,85$ & 0.500 & 793,82 \\
\hline 10 & - & $2,879,70$ & 799,17 & 395,30 & $1,685,23$ & 0.463 & 780,59 \\
\hline NPV & & & & & & & -253.59 \\
\hline
\end{tabular}


Table 2. Cash flows including the transformation of commercial space into office space

Source: Own study.

\begin{tabular}{|c|c|c|c|c|c|c|c|}
\hline Years & Expenditures & Inflows & Expenses & Tax & Cash flow & Discount rate for $r=\mathbf{8 \%}$ & Current value \\
\hline 7 & 500,00 & $2,669,47$ & 753,07 & 364,12 & $1,052,28$ & 0.583 & 614,00 \\
\hline 8 & - & $2,936,42$ & 768,14 & 411,97 & $1,756,31$ & 0.540 & 948,88 \\
\hline 9 & - & $3,230,06$ & 783,50 & 464,85 & $1,981,71$ & 0.500 & 991,35 \\
\hline 10 & - & $3,391,56$ & 799,17 & 492,55 & $2,099,84$ & 0.463 & 972,63 \\
\hline NPV & & & & & & & 125.62 \\
\hline
\end{tabular}

At the initial stage of designing the real estate and in operation, changes are possible, but unforeseen costs could be expected. Therefore, the key element of the strategic property management is to plan the possibilities of its appropriate adaptation (Greden \& Glicksman, 2005). Having options for surface transformation means investments at the stage of designing and realizing the transformable areas. The valuation of non-current options is designed to identify the level of flexibility in investment.

The method of valuation of the switching option boils down to the valuation of related benefits with different ways of using the resources. The method of its calculation consists in choosing a more favorable mode of operation under certain conditions. In the analyzed project, it is not possible to spend money on investment once at the beginning of investment project implementation, which will allow for flexible switching between possible ways of using the resources. Changing the way of using the available space requires the additional expenditures on investment.

The expenditures incurred enable the use of the property in an alternative way while giving up the business so far. To sum up, it is about incurring expenditures (PLN 500 thousand) and changing the purpose of the real estate from the shopping center (SC) to the office space (SC $\rightarrow \mathrm{OS}$ ). The reverse transformation of real estate from an office space into a shopping center (OS $\rightarrow \mathrm{SC})$ will also require the investment outlays (PLN 300 thousand).

The separation of both ways of using the property is the beginning of the evaluation. Table 3 presents the values of individual categories shaping the cash flows related to the previous use of real estate (SC) and the new one (OS).

Table 3 was built on the assumption that the year in which the enterprise intends to carry out a change in the intended use of commercial space for office space is the year 0 . Based on the data from Tables 1 and 2, possible ways of using the available space are described (using cash flows).

The economic efficiency of both business opportunities was also evaluated. In case of trading activities, the updated value $\left(\mathrm{NPV}_{\mathrm{SC}}\right)$ calculated this way equals to PLN 4,994.91 thousand and the corresponding value in case of office activity

Table 3. Net cash flows and their present value in SC and OS

Source: Own study.

\begin{tabular}{|c|c|c|c|c|c|c|c|}
\hline Years & Expenditures & Inflows & Expenses & Tax & Cash flow & Discount rate for $r=8 \%$ & Current value \\
\hline \multicolumn{8}{|c|}{ Shopping centre } \\
\hline 1 & - & $2,374,52$ & 753,07 & 308,07 & $1,313,37$ & 0.583 & 766,34 \\
\hline 2 & - & $2,611,97$ & 768,14 & 350,33 & $1,493,51$ & 0.540 & 806,90 \\
\hline 3 & - & $2,742,57$ & 783,50 & 372,22 & $1,586,85$ & 0.500 & 793,82 \\
\hline 4 & - & $2,879,70$ & 799,17 & 395,30 & $1,685,23$ & 0.463 & 780,59 \\
\hline \multicolumn{7}{|l|}{ NPV } & $4,994.91$ \\
\hline \multicolumn{8}{|c|}{ Office space } \\
\hline 0 & 500,00 & - & - & - & $-500,00$ & 1.000 & $-500,00$ \\
\hline 1 & - & $2,669,47$ & 753,07 & 364,12 & $1,052,28$ & 0.583 & 614,00 \\
\hline 2 & - & $2,936,42$ & 768,14 & 411,97 & $1,756,31$ & 0.540 & 948,88 \\
\hline 3 & - & $3,230,06$ & 783,50 & 464,85 & $1,981,71$ & 0.500 & 991,35 \\
\hline 4 & - & $3,391,56$ & 799,17 & 492,55 & $2,099,84$ & 0.463 & 972,63 \\
\hline \multicolumn{7}{|l|}{ NPV } & $5,559.64$ \\
\hline
\end{tabular}


$\left(\mathrm{NPV}_{\mathrm{OS}}\right)$ is PLN 5,559.64 thousand. According to the adopted scenario in order to transform the retail space into office space, it is necessary to spend PLN 500.00 thousand.

In order to evaluate the economic effectiveness of an investment, the values of the basic parameters, volatility, risk-free rate should be determined, and based on them, the values of increases and decreases and arbitrage probabilities should be calculated. It is also necessary to calculate the value of assets for both uses of real estate.

The measure indicates the tendencies occurring on the market of enterprise functioning in the perspective of transforming a SC into an OS is the relation of square meters of SC to the price of square meters of OS. Based on the historical square meters of SC and square meters of OS, the value of the price ratio index $\left(p_{i}\right)$ was established

$$
p_{i}=\frac{\text { price of square meters } \mathrm{SC}}{\text { price of square meters } \mathrm{OS}} .
$$

Square meters prices in both cases are related to the benefits achieved depending on how the property is used. Therefore, the above relationship can be treated as a twin instrument. The increase in the value of this indicator means that the value of the option, related to the change in the use of usable space from commercial space to office space, increases. In the opposite situation, i.e., the value of this indicator decreases, it will be beneficial to transform the office rooms for commercial purposes. In other terms, the benefits of the possession of retail space are negatively correlated with the increase in the value of the index $p_{i}$, while the benefits of having the office space are positively correlated with the increase of this indicator.

Using the logarithmic method (Mun, 2002) of changes in the value of this indicator, the volatility value was $9.8 \%$ ( $10 \%$ was used for the calculations). Height values and declines in the subsequent years amount to $u=1,103, d=0.906$, and riskfree rate (average yield of 52-week treasury bills) $r_{f}=4.723 \%$. The values of arbitrage probabilities are $p=0.721$ and $q=0.279$. Benefits related to the possession of SC amount to PLN 4,994.91 thousand, however due to the possession of OS PLN $6,059.54$ thousand.

The value of benefits associated with particular variants is represented by the binomial trees in Figure 1 . The value of the underlying asset was multiplied by growth and/or decrease factors $(u$
$4,994,91$
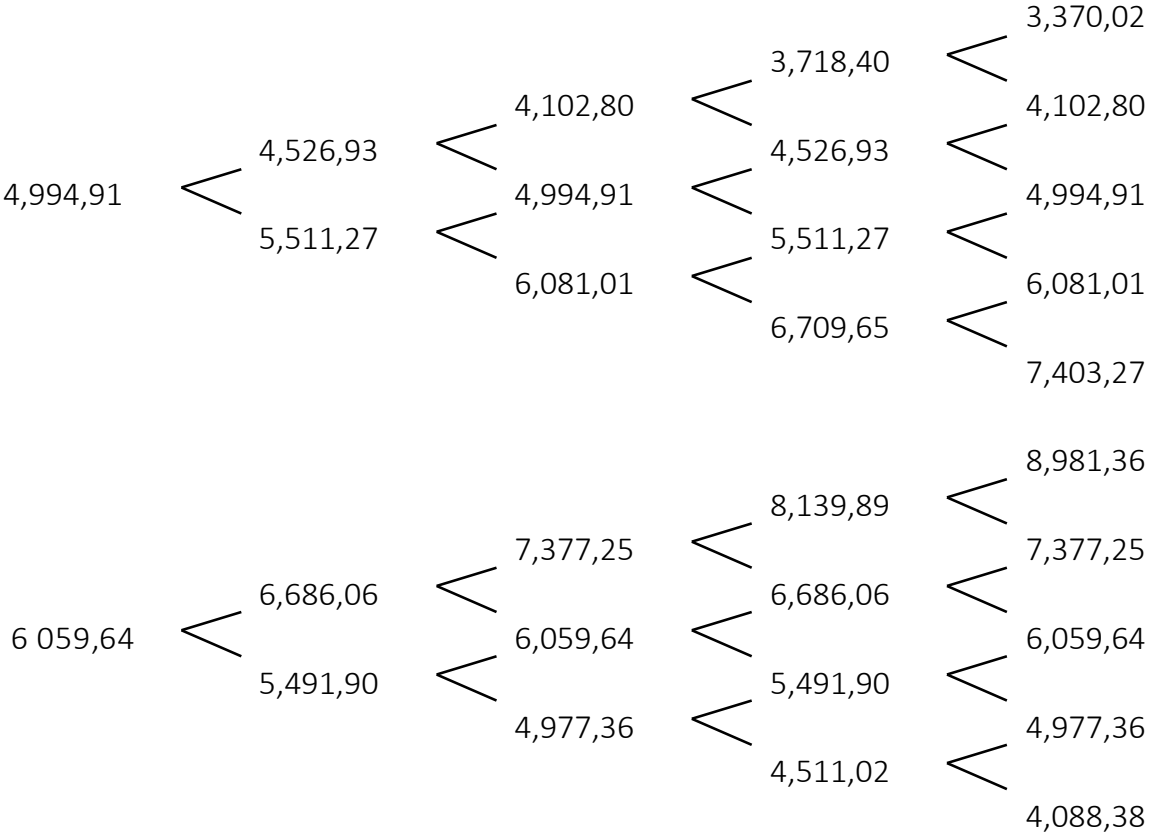

Figure 1. Formation of benefits obtained from having shopping centre SC (top) and office space OS (bottom) 
and $d$, respectively). The switching option is an example of an American sales option, and this determines the way of calculating the values in individual nodes of the binomial tree.

After the stage of building binomial trees illustrating the benefits reflecting different possibilities of using the available areas, the value of the switching option is calculated according to the following scheme (Mizerka, 2005).

$$
\begin{aligned}
& V_{i, n}{ }^{S C \rightarrow O S}=\max \left(V_{i, n}{ }^{S C} ; V_{i, n}-I^{S C \rightarrow O S}\right), \\
& V_{i, n}{ }^{S C \rightarrow O S}=\max \left(V_{i, n}{ }^{O S} ; V_{i, n}-I^{O S \rightarrow S C}\right), \\
& V_{i, n-t}{ }^{S C \rightarrow O S}=\max \left(A 1_{i, n-t} ; A 2_{i, n-t}\right), \\
& A 1_{i, n-t}=V_{i, n-t}^{S C}+ \\
& +\left(p \cdot V_{i, n-t+1}^{i} S C \rightarrow O S+(1-p) \cdot V_{i, n-t+1}^{d} S C \rightarrow O S\right) e^{-r_{f},} \\
& A 2_{i, n-t}=V_{i, n-t} O S-I^{S C \rightarrow O S}+ \\
& +\left(p \cdot V_{i, n-t+1}^{i} S C \rightarrow O S+(1-p) \cdot V_{i, n-t+1}^{d} S C \rightarrow O S\right) e^{-r_{f},} \\
& V_{i, n-t} O S \rightarrow S C=\max \left(D 1_{i, n-t} ; D 2_{i, n-t}\right),
\end{aligned}
$$

$$
\begin{aligned}
& D 1_{i, n-t}=V_{i, n-t} \stackrel{O S}{ }+ \\
& +\left(p \cdot V_{i, n-t+1}^{i} O S \rightarrow S C+(1-p) \cdot V_{i, n-t+1}^{d \quad O S \rightarrow S C}\right) e^{-r_{f}}, \\
& D 2_{i, n-t}=V_{i, n-t}^{O S}-I^{O S \rightarrow S C}+ \\
& +\left(p \cdot V_{i, n-t+1}^{i} \quad O S \rightarrow S C+(1-p) \cdot V_{i, n-t+1}^{d} \quad O S \rightarrow S C\right) e^{-r_{f}},
\end{aligned}
$$

where $\quad V_{i, n-t+1}^{i} S C \rightarrow O S, V_{i, n-t+1}^{d} \stackrel{O S \rightarrow S C}{-} \quad$ project values at the moment $n-t+1$, the benefit tree when changing the commercial space to the office $(\mathrm{SC} \rightarrow \mathrm{OS})$ neighboring with the value in the node $i$ in $n-t$ moment ( $V^{i}$ - increases, $V^{d}$ - decreases), $A 1_{i, n-t}, D 1_{i, n-t}$ - the value of benefits in a situation where the current manner of using the real estate is maintained (SC and OS, respectively), increased by the benefits possible to obtain in subsequent periods, $A 2_{i, n-t}, D 2_{i, n-t}$ - the value of benefits in a situation when at the moment a change in the way of using the real estate from the current SC to a new OS or from OS to SC takes place, $I^{S C \rightarrow O S}, I^{O S \rightarrow S C}$ investment outlays related to the transformation of space from SC to OS and OS to SC, $t=1,2, \ldots, n$, $i=1,2, \ldots, t-1$.

\section{$28,499,83$}

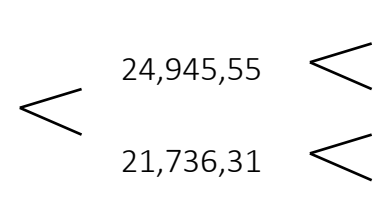

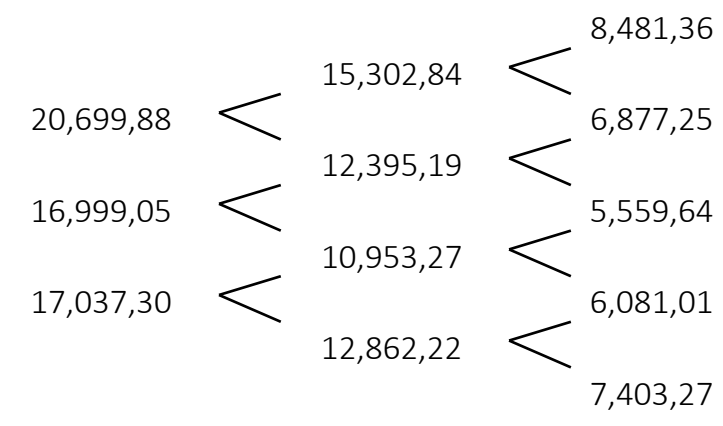

$30,447,91$

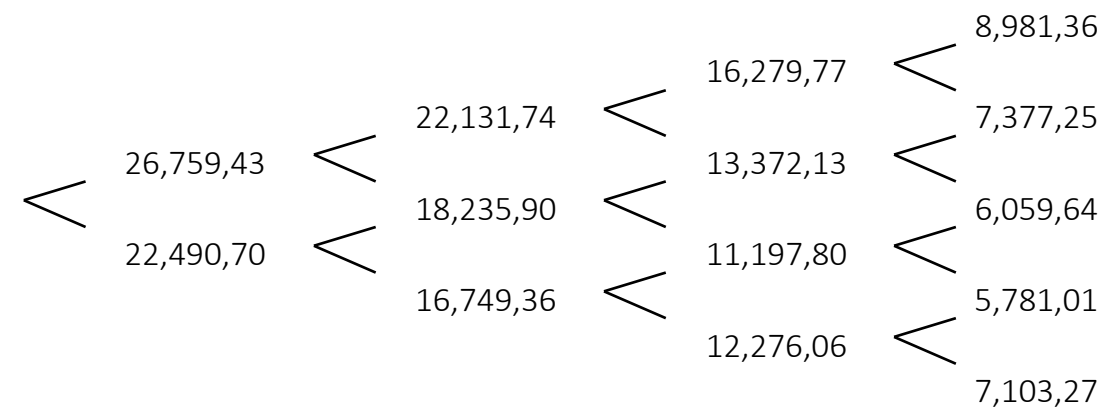

Figure 2. Benefits of changing the SC to OS (top) and OS to SC (bottom) 


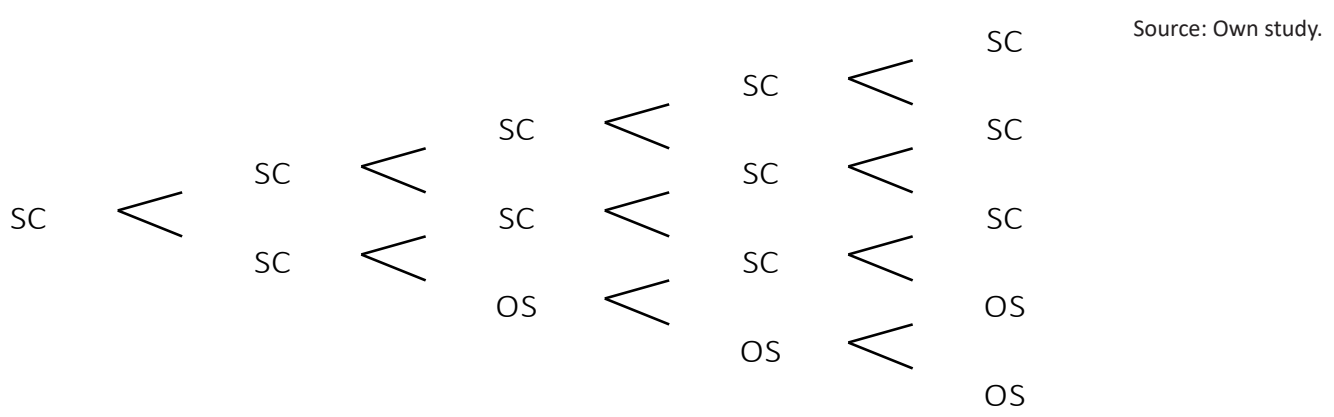

Note: Figure 3 shows the scheme of possible scenarios for switching the way of usage of real estate from SC to OS and vice versa.

Figure 3. Decisions on the use of available space

Tree constructions related to the benefits resulting from the transformation of commercial and office space into commercial space are shown in Figure 2 . The individual values were calculated based on the formulae 2-9.

The value of the project with the possibility of transforming from a shopping center into an of- fice space is PLN 30,447.91 thousand. This is the highest of the obtained values regarding the benefits of the transformation of available spaces. In addition, it should be added that the owner should manage the shopping center (SC), and the option of switch should be carried out only in the four points marked in Figure 3 as OS.

\section{CONCLUSION}

Two-stage evaluation of the economic effectiveness of the investment in a commercial real estate shows significant differences between classical and real options methods. In comparison to the classical methods, real options allow for the formulation and "control" of investment projects, depending on the changing conditions in which the investment project is implemented. An expression of this is the variety of real options that allow using the related flexibility with a specific investment project (in this case, the switching option). So, the results of this research are real options, which were developed on the basis of financial derivative instruments. In case of fixed investments, the real option method allows defining and assessing the selected investment projects.

The practical use of real options is not an easy thing because every commercial property is different. For those who do have foggy idea how the process of investment projects evaluation looks like, the manner of reaching the final results of this evaluation is not as clear and transparent as in the case of using of the classical ones.

\section{REFERENCES}

1. Amram, M. (2002). Value Sweep: Mapping Corporate Growth Opportunities. Boston, Massachusetts: Harvard Business School Press. Retrieved from https://archive.org/ details/valuesweep00mart

2. Borison, A. (2003, July). Real Options Analysis: Where are the Emperor's Clothes? Washington, DC: Presented at Real Options Conference. Retrieved from https://web.mit.edu/ardent/www/ RO_current_lectures/borison.pdf

3. Bryx, M. (Ed.). (2006). Podstawy zarzadzania nieruchomością. Warszawa: Poltext.

4. Copeland, T. E., \& Keenan, P. T. (1998). How much is flexibility worth? The McKinsey Quarterly, 2, 38. Retrieved from https://go.gale. $\mathrm{com} / \mathrm{ps} /$ anonymous?id=GALE\%7 CA21070378\&sid=googleScholar
$\& v=2.1 \& i t=r \& l i n k a c c e s s=a b s \& i s s$ $\mathrm{n}=00475394 \& \mathrm{p}=\mathrm{AONE} \& \mathrm{sw}=\mathrm{w}$

5. Cox, J. C., Ross, S. A., \& Rubinstein, M. (1979, September). Option pricing: a simplified approach. Journal of Financial Economics, 7, 229-263. Retrieved from http://static.stevereads. com/papers_to_read/option pricing_a_simplified_approach. pdf 
6. Foryś, I. (Ed). (2006). Zarządzanie nieruchomościami komercyjnymi. Warszawa: Poltext.

7. Gawron, H. (2006). Opłacalność inwestowania na rynku nieruchomości. Poznań: Wydawnictwo Akademii Ekonomicznej w Poznaniu.

8. Greden, L., \& Glicksman, L. (2005). A real options model for valuing flexible space. Journal of Corporate Real Estate, 7(1), 34-48. https://doi. org/10.1108/14630010510812486

9. Henzel, H., \& Konowalczuk, J. (2009). Ryzyko inwestowania w nieruchomości komercyjne, In H. Henzel (Ed.), Ryzyko w działalności inwestycyjnej aspekty teoretyczne i praktyczne, 2. Katowice: Wydawnictwo Akademii Ekonomicznej im. K. Adamieckiego w Katowicach.

10. Jajuga, T. (2002). Strategiczne zarządzanie ryzykiem przedsiębiorstwa a opcje rzeczowe. In D. Zarzecki (Ed.), Zarzadzanie finansami, klasyczne zasady nowoczesne narzędzia, 2. Szczecin: Wydawnictwo Uniwersytetu Szczecińskiego.

11. Kucharska-Stasiak, E. (2001). Wartość nieruchomości jako kryterium podejmowania decyzji inwestycyjnych. In M. Bryx (Ed.), Wybrane aspekty inwestowania na rynku nieruchomości. Warszawa: Poltext.

12. Kucharska-Stasiak, E. (2006). Nieruchomość w gospodarce rynkowej. Warszawa: PWN.

13. Kucharska-Stasiak, E. (1999). Inwestowanie w nieruchomości. Łódź: Instytut nieruchomości VALOR.

14. Kucharska-Stasiak, E. (2005). Uwarunkowania podejmowania decyzji rozwojowych na rynku nieruchomości. In H. Henzel (Ed.), Wspótczesne kierunki inwestowania - formy i efekty. Katowice: Wydawnictwo Akademii Ekonomicznej im. K. Adamieckiego w Katowicach.

15. Kurek, W. (2000). Metody oceny rzeczowych przedsięwzięć inwestycyjnych. Przemyśl: Wydawnictwo Wyższej Szkoły Administracji i Zarządzania.
16. Kwiatkowska, K. (2003). Obrót nieruchomościami komercyjnymi. Warszawa: Wyższa Szkoła Gospodarowania Nieruchomościami.

17. Lewczyński, W. (1994). Rachunek decyzyjny w inwestowaniu. Sopot: Instytut Przedsiębiorczości.

18. Matkowski, R. (2004). Zarzadzanie nieruchomościami. Warszawa: Katedra Inwestycji i Nieruchomości SGH. Educational materials.

19. Mizerka, J. (2005). Opcje rzeczywiste $w$ finansowej ocenie efektywności inwestycji. Poznań. Wydawnictwo Akademii Ekonomicznej w Poznaniu.

20. Mun, J. (2002). Real Options Analysis - Tools and Techniques for Valuing Strategic Investment and Decisions. Hoboken, New Jersey: John Wiley \& Sons, Inc. Retrieved from https://books.mec.biz/tmp/books/ URSF4SYM38H1V3TRSUZ3.pdf

21. Myers, S. C. (1977). Determinants of Corporate Borrowing. Journal of Financial Economics, 5(2), 147-175. https://doi.org/10.1016/0304405X(77)90015-0

22. Nowak, E., Pielichaty, E., \& Poszwa, M. (1999). Rachunek optacalności inwestowania. Warszawa: PWE.

23. Pera, K. (2010). Zintegrowana ocena efektywności finansowej surowcowego projektu inwestycyjnego. Katowice: Wydawnictwo Akademii Ekonomicznej im. K. Adamieckiego w Katowicach.

24. Petersen, S. B., \& Bason, P. C. (2001). What are real options? Definitions, Terminology, Types. Real options approaches in venture capital finance. Essay Series. Retrieved from http://www.realoptions.dk/pdf/ essay1.pdf (accessed on March 23, 2001)

25. Pluta, T., \& Jajuga, K. (1995). Inwestycje. Capital budgeting budżetowanie kapitałowe. Warszawa: Fundacja Rozwoju Rachunkowości w Polsce.

26. Ruijter, P., \& Janssen, N. (2005). (Real) options thinking and scenarios. Retrieved from https:// www.deruijter.net/publicaties/realoption-thinking-and-scenarios.html (accessed on February 8, 2019).
27. Szmyt-Śmietana, K. (1999). Ryzyko inwestycyjne w transakcjach na rynku nieruchomości. In K. Marcinek (Ed.), Teoria $i$ praktyka procesów inwestycyjnych (Studia Ekonomiczne nr 6, 1999). Katowice: Wydawnictwo Akademii Ekonomicznej im. K. Adamieckiego w Katowicach.

28. Tanas, J., Trojanek, M., \& Trojanek, R. (2019). Seniors' revealed preferences in the housing market in Poznań. Economics and Sociology, 12(1), 353-365. https://doi.org/10.14254/2071789X.2019/12-1/22

29. The Act dated 23 of April 1964 Civil Code. Dz. U. dated 18 of May 1964 with changes.

30. Trojanek, R., Tanas, J., \& Trojanek, M. (2019). The effect of perpetualusufruct on single- family houseprices in Poznań. Journal of International Studies, 12, 212-221. https://doi.org/10.14254/20718330.2019/12-3/17

31. Uhruska, M. (2007). Identyfikacja możliwości kształtowania wartości rynkowej nieruchomości komercyjnych. Świat Nieruchomości, 61, 26-29. Retrieved from http://swiatnieruchomosci.krakow.pl/pl/ archiwum/item/\%C5\%9Bwiatnieruchomo\%C5\%9Bci-2007-nr-361-spis-tre $\%$ C5\%9Bci

32. Uryniak, M. (2011). Ocena ekonomicznej efektywności inwestycji $w$ nieruchomości komercyjne $z$ wykorzystaniem koncepcji opcji rzeczowych. Katowice: Uniwersytet Ekonomiczny w Katowicach. PhD dissertation.

33. Wiśniewski, T. (2008). Ocena efektywności inwestycji rzeczowych ze szczególnym uwzględnieniem ryzyka. Szczecin: Wydawnictwo Naukowe Uniwersytetu Szczecińskiego.

34. Ziarkowski, R. (2004). Opcje rzeczowe oraz ich zastosowanie $w$ formułowaniu i ocenie projektów inwestycyjnych. Katowice: Wydawnictwo Akademii Ekonomicznej im. K. Adamieckiego w Katowicach 